\title{
V. I. LENIN AND THE CASE OF P. N. TKACHEV'S THOUGHT IMPACT*
}

\section{Ondrej Marchevský}

В статье показано, как сама природа философского мышления, морали, этики и также, возможно, более широкой культурной информированности в конкретной области может быть использована как для провоцирования определенной конфронтации, так и для постоянного сотрудничества, внедрения целого спектра более или менее оригинальных инициатив. В качестве примеров анализируются разнообразные типы мышления русской провинциальной интеллигенции, главным образом второй половины XIX и начала XX в. Идеи, сформировавшиеся в этот период, во многом определили дальнейшее развитие русской мысли и нашли разнообразное применение русских философов последующих поколений. В этом периоде также надо искать истоки трагических событий, которые нередко воспринимаются в качестве крупнейшей исторической травмы не только русской, но и мировой истории, причем русская революция 1917 г. еще не самая страшная из них. Исследование сосредоточено на революционной ветви русской мысли, в частности на анализе народничества, квинтэссенцией которого признается деятельность и учение П. Н. Ткачева. Концепция Ткачева, поднятые им проблемы позволяют проследить и подвергнуть анализу его влияние на мышление и политическую практику одной из самых противоречивых фигур не только российской, но и мировой истории - В. И. Ленина. В статье также рассматриваются вопросы об отношении народников к идеям, высказанным Лениным, и о восприятии Лениным идеологии и практики народничества.

Ключевые слова: народничество, революция, П. Н. Ткачев, В. И. Ленин, ленинизм, философская мысль, политическая практика.

Marchevský O., 2020

\section{University of Prešov, Slovakia}

One of the theses proposed in the article is that the very nature of philosophical thinking, morality, ethics, and even any cultural activity can be used both to provoke a dramatic situation, a confrontation in the society etc., and at the same time to stimulate a continual cooperation which may pave the way for more or less original social and cultural initiatives. As examples, the author analyzes various types of philosophical thinking of the Russian provincial intelligentsia, mainly referring to the second half of the 19th and early 20th centuries. The ideas formulated during this period largely determined the further development of Russian thought and later were differently interpreted and used by the Russian philosophers of younger generations. In this period, there should be found the origins of the tragic events, which are often considered as the largest historical trauma not only of Russian, but also of the world history, and the Russian revolution of 1917 was not yet the most terrible of them. The author focuses on studying the revolutionary branch of Russian philosophical thought, in particular Narodnism as it was presented in the works by Petr Tkachev. Tkachev's concept, the problems he raised are analyzed to stress his influence on the thinking and political practice of one of the most controversial figures in both Russian and the world history - Vladimir Lenin. The article also touches upon some topics dealt with the polemics between Lenin and Narodniks. When considering all this, the author took into account the interpretations given by Andrzej Walicki and Leszek Kolakowski in their research works on the history of Russian philosophy.

Keywords: Narodnism, revolution, Petr N. Tkachev, Vladimir I. Lenin, Leninism, philosophical thought, political praxis.

https://doi.org/10.31119/phlog.2020.1.110

* The paper is an outcome of the research project VEGA 1/0231/18 The Drama of Freedom in the Russian Philosophical Thought of the 20th Century. 
Speaking about the Russian intellectual history of the 19th and 20th centuries along with the works of V. S. Solovyov, F. M. Dostoevsky, L. N. Tolstoy, A. P. Chekhov, N. A. Berdyaev, P. A. Florensky, or I. A. Ilyin, there can be seen also the development of strict secular thinking, the aim of which is a change of Russia, a change resolute and rapid, the revolutionary one. It is embodied in works Narodniks ${ }^{1}$ and later in Lenin's activities.

Talking about Lenin - chiefly in the countries of the Eastern Bloc - requires a considerable extent of professional "grace" and "tact". It is a fact that wounds - and not only those physical - are very deep, and that as regards Lenin, it is not possible to avoid views implying mistrust or fear and also animosity, contempt, even disgust. It is important to note that all the mentioned feelings are fully legitimate. For this reason, I would like to make clear that my aim is not to justify or to glorify the Russian radical thought. I approach the radical spectrum of Russian thinking as the historical-philosophical issue, which should be critically reflected. We cannot just close our eyes or adopt an ignoring stance as some kind of "punishment" aimed at the topic. In doing so, we would just repeat the sins of those whom we criticize for the very same thing. And our attitude would be no less radical than theirs. A legitimate criticism should be based on the knowledge of criticised content as well as of the circumstances of its shaping. Thus, the following lines are written to contribute to the knowledge of the phenomenon, not to excuse or rationalize the historical maladies and pathology.

${ }^{1}$ Rus. народничество. Russian Narodnism is a secular movement that use to be called also as the Narodnik intelligence. Having a considerable influence on changes in the social as well as political field, it represents one of the most influential intellectual formations of the second half of the 19th century in Russia. Beginnings of this movement are linked with events such as the death of Emperor Nicholas I (1855), the fall of Sevastopol during the Crimean war (1856), or the abolition of serfdom in Russia (1861). The question of the end of the Narodnism is open. There can be seen different shifts which may be taken into consideration, from the attempted murder of Emperor Alexander II (1881), through the fall of Port Arthur (1905) in the Russian-Japanese war, up to the year 1918. However, an analysis of the Narodnik attitudes enables us to find a set of typical and frequently discussed topics. These include: interest and care of the people, sense of guilt and moral debt as regards the people, will to redeem debt, intention to work for the people's good. Regarding the Narodnism as an extraordinary rich movement, there can be defined some aspects of the Narodnik phenomenon through which it is possible to examine and problematize it. Foremost, we can mention the relation of the Narodnism to the people. To important aspects of the examination belong the study of Narodnism as a political-theoretical and ideological movement. Narodnism as a practical movement may be perceived in two levels. In the first case, it is the public enlightenment, also called the walking among the people (1872-1875). The second one of the practical levels may be identified with anarchism, terrorism, revolutionariness. Narodnism is also reflected as an economical movement, an utopia, an ethical movement, a literary movement, journalism, philosophical thinking. For details see Zverev [11], Broda [1], Pomper [7], Rydzewski [8], Walicki [10]. 
Naturally, the scope of the paper is not sufficient for a complex grasp of such a delicate issue. For this reason, it is necessary to specify my view in more detail.

We can use as the introductory quotation well known idea of Andzrej Walicki "The Narodnik doctrine has been - at least partly - revived in the Leninism. I have in mind the doctrine of Bakunin, Nechayev, and Tkachev in particular" [9, p. 262] which indicates, among the radical Narodnik thinkers the important status is held by Pyotr Nikitich Tkachev ${ }^{1}$. Walicki's

${ }^{1}$ Rus. Петр Никитич Ткачев. *1844 (Sivtsovo, Pskov Governorate) - †1886 (Paris). Tkachev was the son of the well-known architect who died when Pyotr was 7 years old. After the father's death, he together with his mother, two sisters, and brother, moved from the province to the capital city, i.e. to Sankt Petersburg. Mother's principal intention was to secure a quality education for her children. Tkachev was a student at a grammar school. He was extraordinarily interested in activities of G. Garibaldi. After he graduated at the grammar school, he continued his studies at Faculty of Law at University of Sankt Petersburg (1861). During these studies, he began to express his critical attitudes to the existing society. His activities were so intensive that he spent two months in prison during the autumn of 1861. Tkachev was confident about the illegitimacy of his imprisonment behind the walls of the Kronstadt fortress. As Isakov (2010) remarked, that incident sowed the seeds of the radicalization of Tkachev's opinions. As a consequence of the imprisonment was Tkachev expelled from the university. In order to gain an education, Tkachev decided to pay his attention to intensive self-education. He finished his studies extramurally and, subsequently, he successfully defended his dissertation on the rectification of underage perpetrators of crimes. He earned his living as an auxiliary at the law court where he gained enough different materials for an evaluation of the legal and judicial system in Russia. There he laid a foundation for his literary debut, which came in 1862 in the journal "Время" edited by Dostoevsky brothers. Let me remark that at the time already three Tkachev's articles were prohibited by the censorship. Nevertheless, the labelling of Tkachev's articles as prohibited made him even more motivated. He was convinced that it is a sign that he writes about something dangerous from the view of the official power, about something that might change the existing condition. He started to cooperate also with other editorial boards and published his articles in journals such as "Библиотека для чтения, Русское слово" and later "Дело". Aside from the political and economic issues, Tkachev dealt also with questions of law, statistics, the emancipation of women, literary criticism, or history. His articles had a great response throughout the whole Russia. Thanks to his knowledge of German, French, and English language (as a result of his self-education), he was able to get to know many different opinions and attitudes of intellectuals of the time. He also worked on many translations with a commentary, what in turn enriched his domestic intellectual milieu. He was an extraordinarily active person who devoted a lot of time to work, even to writing or to translations, and he was also actively engaged in the political life and its radical spectrum in particular. As a consequence, Tkachev was constantly under the supervision of police, and, due to his activities, he was often imprisoned for short periods. Because of his cooperation with radical circles, he was even punished by the resettlement to the province. From there he fled across the borders to Switzerland on December 1873. During his exile, he attempted to join Pyotr L. Lavrov, but he very soon discovered that their opinions are diametrally different and that cooperation is out of the question. After the 
note also shows that there existed the mutual historical-philosophical and social-political connections between Narodnik thinking and Lenin's attitudes. This paper presents the partial results of my examination of these connections. Its first part is focused on the reflection of Tkachev's original writings. Using the approach ad fontes, I am going to expound Tkachev's conceptualizations of revolution as a radical change, understanding of society, man, action, and progress in history.

The second part of the paper addresses the problem of the possible ideological connection between the Narodnik legacy, and particularly Tkachev's attitudes, and the legacy and works of V. I. Lenin. This examination will result in a sketch of current horizons and visions regarding research of the line Russian Narodnism - Lenin. I will proceed from the work "Idea wolnоњжi u mуњlicieli rosykskich" [9] by Andrzej Walicki, and the second volume of Leszek Koiakowski's opus magnum, "Giowne nurty marksizmu" [5]. Thus, I follow from the works of the historians, whom I consider to be precursors of a new reading of the history of Russian thinking. Despite the attitudes of these historians are not complex, they are original to such an extent that they could form a starting point (not ultimate) of new examinations in the mentioned field of study.

First of all, it should be noted that in the case of all Narodnik authors, one of the fundamental stimuli of their philosophical reflections is the notion of the necessary need for a change of the existing social conditions in Russia of the second half of the 19th century. There can be found various reflections on revolution and violent coup, and also on the overthrow on Tsar and the Tsarist autocracy. However, neither for N. K. Mikhaylovsky nor for P. L. Lavrov is this motive decisive to such an extent as for Pyotr Nikitich Tkachev. Tkachev approaches revolution as the social revolution and he defines it as follows: "A radical change of social and moral relationships of the members of society is called social revolution" [19, p. 651]. In

polemics with Lavrov and also with Engels, Tkachev decided to establish his own press body in order to spread his ideas. His attitudes were positively received by the RussianPolish Slavic circle that held similar opinions as the French Blanquists did. The association was publishing the journal "Nabat" since the end of the year 1875 in Geneva and since 1879 in London. Tkachev became the main ideologist and central figure not only of the editorial board and the journal but also of the strong secret Movement of National Liberation which strived for the overthrow of the tsarist regime and for the revolution in Russia. Tkachev's activities constantly attracted the attention of Russian police which controlled all his communication with the domestic environment and reported on the results the tsar himself. In 1878 Tkachev left the editorial board of the journal "Nabat" and yielded up his position to Kaspar Tursky, a loyal Polish adherent, and moved to Paris. During his stay in France, he managed to make one of his dreams come true when he personally met with Blanqui. That was in 1879, shortly after Blanqui's release from the prison. These two were not destined for a long friendship because Blanqui died in less than two years later, in January 1881. Tkachev was about to be one of the main speakers at Blanqui's funeral, but his intention to say goodbye to his great example was thwarted by the police arrest. Since 1882 Tkachev suffered from serious mental issues which resulted in his death five years after Blanqui passed away. 
this context would be appropriate to mention Tkachev's understanding of anarchy: "Anarchy means a no-reign. But a no-reign is only one of the necessary logical consequences of much fundamental and deeper cause - equality" [14, p. 457]. On the next page of the same work, Tkachev continues: "Equality presupposes anarchy, whereas anarchy presupposes freedom. However, equality as well as freedom - both of these concepts meet in one term, in one word - in the word fraternity. Where is fraternity, there is also equality, where is equality, there is also no-reign and there is freedom as well" [14, p. 458]. Now, we have some notion of Tkachev's starting points. For completion, let me quote his definition of socialism: "Socialism is a socialistic definition of social relationships. It is a definition derived from a consistent scientific examination and a critical analysis of social life phenomena, and it is equally general and valid as any mathematical theory" $[19$, p. 660$]$. I cite this vague definition of socialism without a clearer explanation because it shows a characteristic feature accompanying Tkachev's thinking. I mean his emphasis to scientific and critical analysis, results of which are generally valid. Thus, if Tkachev talks about a need for the change, he sees the possibilities and space for a change as always present. He emphasizes several times that a possibility of change is present also in the situation or environment in which would status quo last even a thousand years. Such a long-term state without changes does not mean that it is unchangeable and valid for good. It should be perceived as a symbol signalizing that certain circumstances have not changed. As Tkachev claims, "social ideals correspond to forms of social coexistence forming them up. If the forms of social coexistence are conservative, if there cannot be found any inner impulse for further development, the ideals will be marked by the same conservative character as well. And in truth, the social ideal of our nation does not exceed petrified forms of its way of life" [17, p. 529]. I have chosen this idea to illustrate how Tkachev perceives his period. The idea, as well as the author, works also with the problematics of determination of social ideals by existing forms of social coexistence. I will return to an analysis of this motive later.

Regarding the legacy of Tkachev's thinking initiative, it is necessary to point out just to his emphasis on a radical change not only in the sense of laying stress on the speed of change but also in a much broader meaning framework. In his view, the radical change implies a radically different social organization than the existing one, which could be applied immediately after the violent revolutionary takeover of power. It should be an anarchistic organization of society. Tkachev's opinions on a radically different society appear in the context of polemics with two anarchistic projects of an organization of social relationships formulated by the Genevan and Brussels circle of socialists. I will not refer to these projects in detail since for a clearer understanding of Tkachev's initial position is sufficient to mention that he doubts their anarchistic character because both of them only attempt to give a new content or even a new attire or uniform to the old institutions such as state, police, army, judiciary, government. According to Tkachev, that is not anarchy. Anarchy cannot consider the state to be the necessity as regards the organization of social relationships. 
Following from mentioned problematization of revolution as the necessary way to a change of social organization, I am going to make a broader entrance to this field of Tkachev's thought. I am convinced that a clearer space for the understanding of his philosophical reflections and his legacy as such can be revealed in this way.

An orientation on group, society, and question of man present the crucial motives that have to be addressed in this part of my consideration of Tkachev's philosophy.

When referring to terms "group" and "society", it is appropriate to emphasize that Tkachev uses these terms in various meanings. By the term group or minority, or more precisely, a revolutionary minority, Tkachev understands such power which should implement a revolution. "We say: A revolution has to be implemented by more or less intelligent and revolutionary tuned minority" [16, p. 515]. An initiator, leader and subject of the revolutionary ferment should be a minority, identity of which Tkachev finds in the milieu of intelligence. This part of society has an education, it is "endowed", and it has knowledge and ability to grasp a revolutionary process. On another place of Tkachev's writings we can find the idea referring to the problematics of a revolutionary minority which allow us to make a better picture on what Tkachev cares about: "When will we finally understand that only unified, disciplined, and closely serried organization may provide the genuine power, that only in this way we can compensate our a little number of us in a sufficient extent?" [15, p. 505]. He specifies the mentality of a revolutionary minority as follows: "In order to change the nation from possible revolutionary power to genuine power, from possible revolutionist to genuine one, we (revolutionary minority), first of all, have to devitalize, weaken, and destroy the political organization devastating the nation and also the conservative, exploitative, and absolutistic state" [15, p. 509]. Thus, Tkachev sees that as the only solution, as the only way out without other options. The notion of the only solution represents an argumentative tool which Tkachev often mentions when he presents his opinions and, as we will see later, he even consciously abuses it. However, Tkachev does not exaggerate the mentioned abuse too much. I formulate this thesis here, within the initial statements, since I am convinced that a deeper immersion in Tkachev's philosophical thoughts will fully confirm my evaluating attitude mainly in the context of a criterion of obviousness which I will analyse later.

When Tkachev writes on a necessity to overthrow the conservative state, he emphasizes an authority of history, which for him represents the base of argumentation and, on the other hand, also the key issue which he tries to cope with: "If the a priori evidence is insufficient for you, look at history. Examine purely folk movements - beginning with the great revolt of slaves in Rome up to the Paris Commune - and you will see that all of these without an exception could happen only when chaos and disorder ruled in the high social circles" [15, p. 509]. In this way, Tkachev formulates his conviction about the necessity of a revolutionary fight and its right timing in the Russian contemporary context. 
By the term society, Tkachev understands, first of all, the target group. Social space is a place that has to be changed. Thus, it is not the man who has his irreplaceable active place in the revolutionary process, and accordingly, it is not the man who should change himself of his own accord. Tkachev insists on a need to change society - only the change is determinative for man as an individual. This view also corresponds with his understanding of man as such. For an illustration, we can mention his view on the radical differences among efforts, aims, and activities of socialists - revolutionists and religious sectarians ${ }^{1}$. "The role of the former, if I can say it so, has purely individual character: a sectarian tries to educate, to transform, to improve each one person separately. A socialist revolutionist attempts to change and to transform those social conditions which influence life and development of the whole society while remaining at the position of the individual. The former influences individual, the latter influences masses" [20, p. 651]. Thus, Tkachev points to a change of the individual through a change of social circumstances where an individual lives and develops oneself. It should be emphasized that, in doing so, Tkachev does not underestimate the value of man as such; he does not consider man being inferior to the whole and the whole being prime. The whole, society, is an important tool. In the context of these reflections, let me note that despite the transformative process is not dominantly based on the activity of the individual, the changes suggested by Tkachev are meant to be primarily aimed at the benefit of each man. That will have an essential impact also on thoughts which I will address later. According to Tkachev, not only a revolution should be realized by the initiative of the minority - the revolutionary minority. It is decisive also for the whole development immediately after the revolution. The situation should be consolidated through a small, hierarchically arranged and stabilized competent minority, a dominant group with clearly set goals.

The revolutionary minority has to work in the perfect concealment before an outbreak of the revolution. Subsequently, Tkachev attempts to point out to a need for the formation of organizations and structure, which will manage this process, such as the socially-revolutionary union, the party. When thinking about this dominant minority as a well-organized group, Tkachev is aware of criticism of opponents aimed at a potential abuse of power by the minority. This context is related to an extensive topic of Tkachev's writings, the topic of the revolutionary party, elaborated mainly in the work "What is the party of progress". The scope of this paper does not allow me to expound this motive more extensively. I will mention just several features relevant for the discussed issue, i.e. what are the foundations on which the revolutionary social change should be successfully implemented.

${ }^{1}$ By the term religious sectarian Tkachev designates the adherents of the Russian religious philosophy who represented the strongest ideological and philosophical opposition to the Narodnism as a secular stream of thought. We can mention Vladimir Sergeyevich Solovyov as an example of the representatives of the Russian religious thinking in the second part of the 19th century. 
When talking about the question of a change of society through a revolutionary coup, we should pay attention also to Tkachev's understanding of man. As I mentioned above, in Tkachev's view, an individual man does not play any principal implementing role. It can be seen also in a free usage of the terms man, individual, and person in his works. The notion that man is a product of society and his surroundings may be regarded as the dominant attribute of Tkachev's characteristics of man: "Human self is a product of a long sequence of causes; it fully depends on an environment in which one lives. It is connected by uninterruptible ties with many other human selves which have preceded it and of which it is a contemporary and which determine its action. In short, it is only one of the small links in an endless chain of causes and consequences. In other words, it represents one of the manifestations of that necessity, which was in the past laid as the opposite of freedom" [21, p. 140]. Thus, Tkachev emphasizes the influence of society on individual in such a way that society not only determines man, it even determines how a man perceives oneself within categories such as freedom of action and thinking: "Our consciousness of own freedom in thinking and action is nothing more than a consciousness that all our thinking and action is dependent and determined by our self, i.e. an aggregate of those diverse physical and psychical causes, those affective and intellectual states, which we have agreed to call our self, our character, our will etc." [21, p. 141]. Another principal attribute of man is his egoistic nature: "Majority of people in the majority of cases do not act on noble principles or abstract ideas, but on an ordinary calculation" [23, p. 130]. At the other place, he notes in the similar spirit: "If we perceived man separately, in isolation from other people, it would be undeniable that each man always thinks and acts upon his private interests, for his advantage, own benefit, own welfare. That represents the only stimulus of human activity" [23, p. 120]. Afterwards, he adds also the second, social, side of man: "For the confirmation of the truthfulness of human utilitarianism, it is appropriate to look at the results of an impact of the whole society understood as a connection of many human individuals" [23, p. 120]. The result of these statements is the following question: "Where does that peculiar contradiction between the individual effort of each man to reach personal happiness and the consequences of the influence of society which bring a direct opposite of any personal happiness come from?" [23, p. 120]. Tkachev writes that the majority of respected philosophers and theologians have explained this issue by an influence from the outside, by the influence of some power out of man. In this way, the issue is transformed into the eternal problem, which is only apparently explained by individual conceptions - including religion. Tkachev does not agree at all with such a way of explanation and he states that this issue is possible to solve in generally valid level. However, in doing so, he does not deny that it is not only an intrinsic human action. That conviction or, more precisely, such formulated demand of a general validity will play an important role in the formulation of further thoughts of this Narodnik thinker.

The motive of action and decisiveness in action represents another fundamental feature in Tkachev's thinking, which is probably not very surprising if we take into account the abovementioned thoughts. It is understand- 
able or possible to suppose that the author who puts such a great emphasis on the change of social organization through a radical way will stress that motive. Take a look at his answer to the question concerning the role of moral ideal and the need for its implementation: "Morality of a certain environment is not determined only by the extent, meaningfulness, and humanity of its moral ideals, but mainly (and that is fundamental) by its relationship to these ideals. Man can have an extensive and meaningful moral ideal, but if $\mathrm{s} /$ he will not even move his or her finger for its practical implementation, if $\mathrm{s} /$ he does not implement it into his or her life, if $\mathrm{s} /$ he does not project it into his or her action in society, then nobody will consider such a man being moral" [22, p. 449]. We can notice that here Tkachev refers to man as an individual. Nevertheless, I have chosen this idea mainly as appropriate illustration of the motive of action. The idea is interesting also because on the one side it determines a need for decisive action but on the other side, as I will try to show, the motive of action and implementation of a certain ideal opens for Tkachev a problematic space. According to the Russian thinker, it is crucial to answer the question which may be formulated in the following way: What ideal should be fulfilled, according to which one should we act? Thus, Tkachev is interested in what a revolutionist should implement. Precisely speaking, Tkachev is in a certain way distressed by the notion of many ideals that could be imagined and also by the fact that any ideal can be neither the only one nor the only correct one. Tkachev, who emphasizes the principle of general validity and necessity, sees in that not only a problem but the essential mistake. An accompanying problem of this relativeness is frequent excessive concentration on the question how to justify and determine the right ideals, which according to Tkachev do not lead to any results and do produce a vicious circle of constant questioning without a possibility to reach a clear idea of what has to be implemented. It is not hard to imagine that within the intentions of Tkachev's works, this issue is extraordinarily serious if we take into consideration what he so frequently emphasizes. According to Tkachev, the value of ideals lies mainly in their role of the goals of action and implementation of changes.

So far I tried to introduce those elements and issues which in a considerable extent influenced Tkachev's opinions and which emerge from the need to implement a radical social change in the form of a social revolution implemented by a small group of revolutionists, i.e. to adjust social conditions on the grounds of generally valid determinations to be able to have an influence on individual. We can imagine what causes a problem also beyond direct Tkachev's statements. However, it should be reminded that the central interest of this paper lies just in the works and opinions of the Russian thinker. The following statement can be understood as a milestone in the reading of Narodnik thinker's works: "The preparation of a revolution is not a role of a revolutionist. It is prepared by exploitation-men - capitalists, landowners, popes, police, office workers, conservatives, liberals, progressivists etc. Revolutionist not only has to use and in an appropriate way combine the elements that are complete, given, created by history, and emerging from a social life of a nation, which are consolidated and developed thanks to an obtuseness of protectors and nonsense of governments with 
their policemen and armies... Revolutionist does not prepare a revolution, he implements it. Let's go forward! Let's go quickly! All indecisiveness, each delay is criminal" [14, p. 455]. The basis of a revolution depicted in representations of social determinations covered by a motive of capitalists, landowners, popes, police, or public servants, is, as I suppose, quite comprehensible. I consider the given idea to be a milestone in the reading for that reason that a revolutionist is not the one, who prepares a revolution, but he "only" implements it, and he does so with the help of a certain set of instruments which are unknown for us yet. At this moment, the mentioned inspirational task may be crystallized more clearly on the background of a demand which Tkachev formulates as follows: "What does, in general, determine the revolutionary powers of this or that social environment? They are determined mainly by two prerequisites: by the character of ideals in a given environment on the one side, and by their relationship to the reality of the real life on the other" [17, p. 527]. Here we can find a more detailed notion of the abovementioned need to determine an ideal that should be implemented since it represents the fundamental determination of action as the most dominant activity in general. The second side enriching our reflections on Tkachev's works is the relationship to a reality of the actuality. By that Tkachev understands the relationship to that what in fact happens in society. An inspirational mission of those who prepare a revolution lies in their task to determine the ideal and to find instruments for implementation of changes in society in order to satisfy social needs. Tkachev frequently points to a problem of the separation of conceptions of thinking from the real life. In consequence, it only contributes to - besides an absence of a general validity of ideals - an impossibility to act according to them. The importance of a criterion of rooting the thinking in social action and its needs as well as applicability into this environment is illustrated also by the following idea: "It is understandable that among all writings, the greatest significance for us do have those ones which clarify to the youth its revolutionary ideals, give the youth advice and examples of a revolutionary praxis, those which deal with basic questions of its activity in this or that way" [21, p. 174]. These writings form one of the basic frameworks within which Tkachev presents his thoughts. He actually has an indubitable ambition to enter just this space and to deal with practical use of ideas right in the revolutionary and post-revolutionary environment of the second day after the revolution when the social relationships will be consolidated anew. An urgency of these requirements associated with the time when Tkachev was writing is expressed by this statement: "A revolutionist has not yet realized, how and by what the replacement of the existing abnormal organization of social relationships is required, he still has not even created any ideal of a light future in his head. So far, it is impossible to expect some extraordinarily useful results in his action, there cannot be seen any manifestation of stableness, neither consistency nor purposefulness" [19, p. 543]. Stableness, consistency, purposefulness represent the building stones of possible changes and action of a revolutionist that, however, - as yet - have not been fulfilled, and a revolutionist himself is unable to do that since it is 
not his scope of activity. A revolutionist waits for the goals which he has to fulfil and also for the tools by which he will fulfil the goals.

In order to define a wider context into which are set Tkachev's philosophical thoughts, mainly on history, I consider being necessary to introduce the author's attitudes in two, or more precisely, three mutually interconnected time levels in relation to the act of revolution itself.

Firstly, there is a certain preparatory period that on the one side lies in a deterioration of social situation to such an extent that the change through a revolutionist and, in fact, through a violent coup appears as inevitable, and on the other side, within the mentioned period, the change is formed as a product of escalated social situation in the level of ideology, philosophy etc., what makes a platform of the revolution itself. The second period is aptly named by the title of one of his works: "On the Eve and the Day After the Revolution". It is a period of the implementation of a revolution itself and simultaneously a period of changes which will arrive after the revolution is finished. The changes which come after the overthrow of the existing regime are the long-term sequence of events, and for this reason, I have outlined the evolution of Tkachev's thought in two, or more precisely, three periods. Tkachev himself understands a radical transformation of society as a long-term process. It represents another level of Tkachev's objections to the conceptions of the Brussels and Genevan socialists. According to Tkachev, they do not deal with how this change will practically arrive at all. It seems that they consider a new organization being fallen down from heaven, as it would be clearly given, working and fulfilling all socialistic ideals. However, they do not even have an idea of how could all this be established.

If I wrote on the need for an ideal for the implementation of revolution, it is necessary to note that these Tkachev's reflections are tied with the content of the term progress. Just the idea of progress has for the revolutionist a principal significance within a directing of his action.

I have also mentioned that in the preparatory phase of the revolution, besides social conditions, the significant role is played also by those factors, or those ones, which Tkachev does not delimit in any clear way. However, it can be understood that they create conditions for the implementation of the revolution. Tkachev's views on history indicate that the work of historian

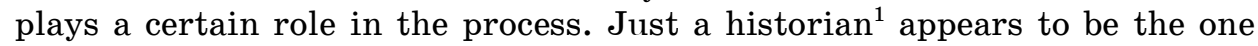

${ }^{1}$ In this context, the still open question is, who exactly should be that power, the element that will determine the clear direction of a revolutionary change. Based on my previous study of Tkachev's works, it is possible to think also about philosophers, journalists, and writers besides historians who appear to be the most acceptable base. Mentioned unclarity leads up to the question, whether Tkachev could deal with the issue in any of his works which have not been preserved. In relation to Tkachev's works, there can be found some reactions on works which are ascribed to this Narodnik and which are not preserved (such as work “Эстетическая критика на почве науки”). It is also well possible that the question refers to an open issue that the Russian thinker intended to problematize later. There are several places in Tkachev's works where the author declares that he will elaborate a certain question in a separate work in the future, however, 
who plays a significant role within the preparatory phase of a change - next to the overall social atmosphere. His mission lies in an understanding and appropriate explanation of progressive or regressive phases in history, and also in the definition of what is progress as an ideal that a revolutionist has to implement. Tkachev presents in detail his notion on what elements a reflection about progress contains, in other words, what kind of reflection could be called as progressive: "I pointed to essential, inevitable elements of the term progress. It necessarily has to contain the notion of a movement in one determined direction for the achieving of a certain goal. Movement, determined direction, and goals - these are three main moments of the progress" [13, p. 296]. In this context, he later formulates another principal idea: "If a movement is needed, and if this movement goes in one and the same stable direction, then we examine this movement as a progressive one" $[13$, p. 309]. He points out in another place: "What is the notion about progress? It is a metaphysical product of a teleological world-view. Progress supposes a purposeful movement, a development directing to the achievement of certain result which is considered to be its criterion. Without a notion about the goal is a notion about the progress unthinkable" [12, p. 249]. As I outlined, Tkachev characterizes only those elements which create the term progress. It is necessary to address the problematics of a goal and criteria of movement in one stable direction without a consciously determined goal or with a goal that is unclear. Tkachev, in a certain way, explains the existence of progress without a possibility that it could be perceived as progress independently on the moment of a clear goal. At the same time, he creates a space for an explanation of existing interpretations of progress to which he assumes a critical attitude. Among the moments of progress, the goal along with a movement is determinative. Both of these criteria, both moments, may assign to such process the name progress. As we will see later, this will have an essential significance for Tkachev, since he considers the determination of the goal to be so peculiar that nobody took it into consideration in a real action so far. Thus, what absents here is the moment of discontinuance of movement referring to a certain sequence of events which, in Tkachev's case, still yet to begin. I will return to these motives later and I will try to expound them in a detailed way in the context of transformations founded in Tkachev's works. I would like to emphasize that he understands these elements as objectively valid components of the term progress, while he sees the movement itself as a conscious action, an activity. Here we meet a problem linked with the postulating of a certain objective validity of the elements of the term progress which is neither rooted nor argued in detail anywhere. It seems that Tkachev presupposed that there exists something such progress itself defined by these attributes which should determine it as objectively established and independent on

he did not manage to write it (we can mention the motives from the works "Педагогика - родная дочка психологии” or "Издательская и литературная деятельность Благосветлова"). We may assume that only Tkachev himself is able to properly determinate this revolutionary directing. This footnote should be perceived as an indication of a certain problem which I intend to cope with in the form of a separate paper in future. 
subjective evaluations. As we saw, the elements of the direction and goal can be also understood as constituents enabling movement in any direction and, in doing so, they enable this movement to become progress. It brings considerable problems since these variables may be fulfilled with various contents depending on individuals or differently determined societies. In this variability, Tkachev sees one of the greatest issues of the examination and social change. The main scheme of the problem can be outlined in the following way: The ideal of progress is an inevitable stimulus for action, but its content may be varied. He formulates one of his negative attitudes to an existing understanding of the historical process as follows: "The theory of a movement in the circle is quite dismal. It is terrible to think of that that human history presents a long time ago told fairy-tale, that there cannot be found anything new and unexpected, that the future will be only a restoration of the past, that people are sentenced to the Sisyphean work, that a stone of civilization is pressed to a steep peak of progress only in order to fall to its bottom again" [13, p. 304].

In the connection with the term progress, Tkachev pays attention to an issue which could be called an issue of the content emptiness of the term progress. Tkachev writes: "There are not so many words in the everyday life of a society which would be so frequently, or more precisely, constantly abused as the word progress" [13, p. 277]. Tkachev sees that as a great problem; according to his opinion, this term has been emptied in social discourse, although it has the essential status in relation to social events since it represents a fundamental determination for a division of society to those who fight for a progress and those who may be called as conservatives and routine-men. Based on this criterion, also groups of co-fighters and enemies are defined: The sides proceeding from a certain determination of progress (even if they are called by the other side as routine-men and conservatives) may freely define these groups because of the content ambiguity of the term.

Tkachev mentions an interesting example with shops in a city. If all shops in a city were termed only by the same word shop (he uses it as a parallel to the term progress), we would not know what is sold there, and thus we would have to visit all of them to buy everything we need. He admits that, after some time, we could get oriented in shops and streets and we would exactly know where we can buy this or that, and thus we would not have to go to all the shops over and over again. The problem here is that everybody calls oneself a fighter for progress, but each one "sells" his progress, and if we get oriented, then we know which understanding of progress is provided in this or that "shop" and, thus, we can visit them according to our preferences. However, until we will get oriented, a butcher's shop will sell to us its progress similarly as a textile shop will sell its one. Such selling of different kinds of progress may cost us a lot of time and worn-out shoes. And imagine, as Tkachev warns, that you move among several cities for several consecutive days and you need to shop everywhere. Tkachev points out also to a situation that you would ask for a certain item in the shop where it is not sold, and they will send you to a wrong shop either consciously or because of their stupidity; they will send us to a butcher to buy a coat. Tkachev tries to 
say that even these "dealers" do not have to know each other. Tkachev says that it can drive us crazy and that such a problem concerns everyone who wants to evaluate people around by the category of progress, in other words, to divide them into progressive and conservative ones, because it is not clear which brands of goods they prefer, where do they shop, and to what extent do they know a local offer.

In this way, Tkachev points to the problem of a definition of the term progress which, according to Tkachev, becomes only the empty form in communication, and an arbitrary scale of contents may be ascribed to it. It is necessary to put an end to the ambiguity of this kind once and for all. It is necessary for the effective implementation of revolutionary efforts. On the way out from a dangerous and insane stalemate, the Narodnik thinker provides a criterion that has to be implemented to determine a clear, in Tkachev's view, objectively valid vision of progress.

The criterion is obviousness ${ }^{1}$ : "And such criterion does exist and it is not any phantom or desire. That criterion is obviousness, however, not in that vulgar meaning so often used in society in order to express an ordinary subjective conviction about legitimacy, i.e. truthfulness of this or that, but in that more exact meaning, according to which an obvious denotes something that every subject would consider being undoubtedly convincing, i.e. true, independently on his or her opinions" [13, p. 285]. This is the fundamental argumentative thesis of his objectively valid conception that creates a basis for other explanations leading to the foundations for an action of an impatient revolutionist. Tkachev wants to explain the character of that something": "We are justified to consider these somethings being true in themselves because they are true not only for me or for you, but for all people in general. And if moral world-view of a man may be brought to unambiguity binding for all subjects, then do not say that it is true only for him, for that one concrete man. No, it is true in itself because it has to be true for everybody" [13, p. 285]. By such, for Tkachev clear (although for a reader certainly incomprehensible), way the author creates foundations for objectively valid or existing somethings in general. Since Tkachev's efforts are primarily oriented to a practical sphere of action, to a need for transformation of the country, he is not idle and he specifies that objective somethings as the fact of the goal of progress that, up to now, has been presented as the element of the term progress.

The goal becomes a necessity in the life of society: "Society without a goal is logically unthinkable, therefore the fact that in social union ${ }^{3}$ is a goal always present is the fact fully objective" [15, p. 313]. On the other place, Tkachev adds in a similar spirit: "We cannot impose goals on nature, but we can and even must do that on the human society" [12, p. 251].

\footnotetext{
${ }^{1}$ Rus. очевидность

${ }^{2}$ Rus. нечто. Tkachev uses the Russian equivalent for something in the plural.

${ }^{3}$ Rus. общественный союз. Tkachev uses this term often, however, he does not specify it in detail. That indicates, Tkachev uses it only as a general term denoting society.
} 
Subsequently - after the clarification of objective foundations of progress - Tkachev formulates an important question: "If human life has some objective goal that is obvious for all the people and everyone, then why this goal is understood so differently by various people?" [13, p. 313]. Even in this case, Tkachev offers an objectively valid, and thus "obvious", answer: "All thinkers (of course, excluding those who investigate society as an independent organism having its own organic units) agree that people form a society in order to be able to implement their human, individual goals in a better and fuller way. Therefore, a collective union of men cannot have any other task besides as full and perfect implementation of life goals of its members as possible. All of them also agree that a connection of these life goals may be included in one goal - in a man's effort to live a happy life, to achieve happiness. According to a general opinion that is the goal of each human existence" [13, p. 314]. Here we meet an attempt to provide a genuine complex explanation of an objective validity which can cope with uncomfortable thoughts in a peculiar way - either by denoting them as subjective fables or by tucking them into a corner of nonsenses not worth of commenting and wasting time. Later, we meet with the notion of happiness as the objective goal: "The goal of human society is identic with the goal of the individual, and that is human happiness. This goal may be called the objective one. It is obvious to such an extent that it becomes obligatory for human reason" [13, p. 314].

On the origin of happiness as a determining measure and criterion for assessing the ideal of progress, Tkachev writes: "This measure, which is a priori so to speak, is inductively derived from history of human life in society; it has been adopted from the essence itself, from the goal of this social life" $[12$, p. 251]. Let me quote an extensive statement where Tkachev tries to solve, in a peculiar way, also an issue emerging from an obvious reality of human needs, and which could objectively relate to all the people: "Society may fulfil its tasks in a full extent only if: first, it will connect life goals of all the people, i.e. it will create completely equal conditions of education and, in the future, it will bring all chaotic heterogeneities made by individual during regressive movements in history to one common denominator, to one common level. Second, it will achieve harmony of means and needs, i.e. it will develop those needs among its members which are possible to satisfy by the productivity of work, or which may immediately increase productivity or decrease losses, those needs which are necessary for support and development of the individual. Third, if there will be a certain possible extent of satisfaction for all needs of all the people equally guaranteed (we say: a possible extent because the establishment of absolute harmony between means and needs represent only barely reachable ideal). Implementation of all these three conditions in as full extent as possible represents a final goal of society. It is a goal completely objective that emerges from the essence of life in society itself. Human life in society cannot have another task than to help to implement the goals of individuals which constitute the society" [13, p. 321]. The mentioned quotation from the work "What is the party of progress" allows, as I think, to make a clear idea of the understanding the term happiness within the conception of progress. It represents an objective goal 
that as an element of progress becomes the objective goal of progress as such. According to Tkachev, that is an original output that none of those subjective idealizing or religiously idealizing sectarians has ever managed to do. If I indicated in my description of the elements of progress that Tkachev specifies the determination of progress by the connection of movement as a conscious activity with one of the elements, with a goal or uninterruptedness of this movement not by a chance, now we can see this intention more clearly. As I mentioned, according to Tkachev, nobody has determined such objective and obviously clear criteria of progress so far, nobody has determined the goal of progress in such an objective way; so there would not be possible to think about progressive thinking if progress necessarily consisted of all three objective elements. It would not have any historical representation in this undivided form.

Postulating of the objective progress take us only a step from all great possibilities which this discovery based on obviousness will enable.

As a key for the entrance to a new world that has not been objectively known so far, Tkachev uses economical interests. These have been already partly formulated by him.

Economical factors are, according to Tkachev, dominant elements in the whole history. He writes: "Neither moral doctrines nor critical thinking moves the history or create its genuine content which is determined sovereignly by the individual affects, by the subconscious, almost completely instinctive needs. These affects, these subconscious needs are determined by the economic interests of that environment in which they arise and are developed. They are some kind of nerves of social life, a soul of history, on which all the attention of a historian is concentrated" [21, p. 173]. On the effect of economical causes, Tkachev writes in other work: "Economical causes, as we can saw, have created and supported all the enormous nonsenses which tortured and excruciated human reason during so many centuries. The same economical causes have eliminated and destroyed all those nonsenses as soon as the need for them disappeared. The fact that all the wisdom of intellectuals and all the beautiful speeches of apostles could not be implemented was caused by the economical interest itself" [23, p. 129]. Tkachev demonstrates the power of economic influences on several places, such as: "When a factory owner yields a certain percentage of profit, when a shopkeeper decreases the price of goods, when Englishmen bought slaves in their colonies and English barons, in turn, bought their serfs, then believe that the stimulus was neither philanthropy nor love to humankind or any humane motives, but an ordinary arithmetic calculus and nothing more" [23, p. 130]. Tkachev even claims that also religious determinations are subjected to this economical factor: "In most cases, every private business has had also some religious goal. Business expeditions have been at the same time the missions, and missions - business expeditions" [23, p. 131]. In this connection, he mentions also the crusader expeditions. However, he also writes that the church with its teaching was often a considerable obstacle in the development of business and market, i.e. businessmen frequently had to fight with the authority of the church, what often caused that the economical power prescribed operation of the church, and the church was an apolo- 
gete of economical interests. A few pages below, he adds in the same spirit: "A dominant philosophy, religion, and science do not represent anything else than a mirror in which the economic needs of a nation is a certain period are reflected and repeated with a mathematical accuracy" [23, p. 133]. He goes even further. "All great changes that have been realized in human world-view within a moral sphere and in a sphere of thinking arrived by the influence of given economical relationships, of given economic interests. As we saw, these changes were happening unobserved, gradually, they had not been in accordance with great scientific discoveries, they had not been made by the power of some genius or the whole group of extraordinary thinkers. Thinkers started to spread disbelief, tolerance, or utilitarianism long time after the economical calculation has changed people's views on the infallibility of the catholic dogmatism and on the role of suffering and hedonism in human life" [23, p. 149].

Thus, it is apparent that the power of economical influences does not evade even the sphere of the state, politics, and law, as we can saw, while the role of the economic element in the legal field still has not been sufficiently explained. In this connection, Tkachev writes on the role of economic influences: "In general, it is possible to say that economical relationships determine the main and key elements of a state organization. Details and particularities are, of course, determined by a given level of thinking in a country" [25, p. 438].

The abovementioned sequence of Tkachev's statements represents one of the results of his new and objectively valid characteristics of progress that establishes the happiness of individuals of the respective society as the goal of social life. Just the determination of objective criteria helps us to uncover the number of falsehoods and injustices which happened and are still happening, falsehoods and injustices which were conditioned by economical influences and excused by anything, and which were perceived as plausible at the time.

To explain the arisen state, I consider being necessary to pay attention to one essential element which plays a significant role in economic relationships. It the given context, Tkachev emphasizes capital: "All qualities of man, everything $\mathrm{s} /$ he has, everything $\mathrm{s} /$ he wishes for, everything $\mathrm{s} / \mathrm{he}$ strives for, all that has a significance for man only to such an extent to which it can be capital. Having a capital, that is the highest good, that is his/her final goal, and that is also what $\mathrm{s} /$ he fights for" [25, p. 434]. He deliberates about capital also in the sense of mental capital: "What an allembracing and dominant status in the consciousness of a majority the term capital has. Everything, certainly everything, even also honesty, greatheartedness, or love falls into the category of this term" [25, p. 434]. It can be seen that Tkachev understands the capital in a very wide meaning.

A wider meaning of the term capital is not accidental. On the grounds of his objectively determined goal of progress, Tkachev sees in the capital the key issue of the whole history: "Means for survival - too little for a historical man, he needs to have them in the form of capital. If $\mathrm{s} /$ he once reached this goal, s/he will cease to belong to herself or himself, s/he will completely give herself or himself to the hands of this affair, possession of 
which s/he strives for. Capital does not belong to her or him, s/he belongs to capital, s/he does not manage capital, but capital manages her or him. It forces her or him to constantly wage a fight which s/he does not wage for herself or himself, but for capital. At this moment, the fight loses any form of the fight for survival. Our attempt to find any reasonable mental grounds, any real or meaningful need for this fight in human nature would end unsuccessfully. No, man does not act on the grounds of own logic, but on the grounds of the logic of capital" [25, p. 434]. This idea refers to a certain digression made by humankind in relation to capital. The thing we yearn for and want to achieve has dominated the humankind to such a degree that it has become completely subjected to that thing. In the result "the accumulation of capital and economic progress indeed undoubtedly help to the development of an activity of reason, but only, so to speak, in a quantitative and not also in qualitative ratio" [25, p. 436]. The development can be understood as the determination of thinking by something what sort of allowed the accumulation of capital. As one of his merits - besides the objective goal of progress - Tkachev considers also the mentioned revelation, a new view or rather an impulse for the revaluation of history. From this viewpoint can be seen that all ideals and values which had been established in history as dominant stimuli of particular historical periods, were determined by the economical conditions fully dominated by the pursuit of capital over which the humankind lost a control. This issue completely disappeared from the objective - and the only possible - goal of history that is human happiness. The capital that should contain a variety of goals and happiness became an unawareness of the genuine goal of human society, a slaveholder ruling the society.

Manifestations of perversity following from the subjection of philosophy and thinking to the capital can be seen, according to Tkachev, also in great thoughts and ideals formulated by bourgeois thinkers: "Bourgeois thinker sums his understanding of social ideal in this way: What is the individual in contemporary society? It is nothing. What it should be? It should be everything. What is the state in contemporary society? It is everything. What it should be? It should be nothing" [24, p. 349]. The quoted Tkachev's idea evokes the political context of his work when he writes about bourgeois thinkers' approach to the role of the state: "In a word, the state is transformed from a political and legal institution to an insurance company" [24, p. 349]. An unprecedented example of such bourgeois thinking is, according to Tkachev, the French publicist and philosopher of law, Йmil de Girarden, on whose philosophy he writes: "Whole philosophy of Girarden which deals with an impossible task to conciliate the irreconcilable - the freedom in a legal sphere with the freedom of capital - is inwrought by a number of contradictions covered with sophisms and smoothed down with layers of pointless phrases" [24, p. 351]. Later, in relation to the French thinker, Tkachev adds: "Yes, that is the apotheosis of tyranny. Tyranny, the enslavement of individual; that is the final synthesis of all contradictions of that principle of the absolute individualism, which is preached by bourgeois philosophy" [24, p. 364]. He points to the inability of bourgeois philosophy to liberate itself from the subjection to capital, the subjection that bour- 
geois philosophers do not want to admit. On bourgeois philosophy, Tkachev also writes: "It uses a raw empiric material in order to fulfil arbitrary frameworks of its metaphysical systems. Since systems are not able and cannot lead anything to mutual accordance, there cannot be any harmony, any unity. They cannot uncover and clarify those unconditional scientific laws, without knowledge of whose social philosophy will stray in the dark forever, and will be getting lost in its own contradictions, while bowing down to praxis with flatterness of a slave as its echo, instead of courageously analysing and ruling it. It takes pride that it strictly follows the facts and does not admit any fantasizing; it calls that as a sober realism" [24, p. 371].

And thus, Tkachev's works may be characterized in the following way: The central point of his interest is the effort to determine the objectively valid criterion of progress as the ideal which regulates human action, or more precisely, the systematically elaborated revolutionary action. With its organization, it reminds the structure of army with officer's staff and the ranks, or to be more precise, in Tkachev's view, the strong party with an executive controlling unit such as a committee, and ordinary members of the party, the executors of revolution. For Tkachev, this ideal with its stimulating function is tied chiefly to a group of revolutionists, ergo to those who practicably execute a revolution. In the process of the determination of the objectively valid ideal within Tkachev's conception, an important status is held by a historian and history as a science working with the past, which is perceived as a space full of different events, social phenomena and changes. Just history represents the soil that is able to most effectively absorb and use influences of objectively and absolutely valid truths. At the same time, it is able to revaluate its own impact and also the mistakes which have been done in other fields of human active action. And finally, history may provide to revolutionists everything they need for the implementation of revolution and for the transformation of the country during "the second day after the revolution".

We can imagine that the confrontation of Tkachev's opinions with his contemporaries as well as with latter historians of philosophical thinking resulted in sovereignly critical attitudes to his works. Many of them would recommend placing the works of the Russian Narodnik into archival funds titled Never read that again - brash nonsense. Despite the mixed feelings caused by the mentioned imaginary title, I consider a further work with the thoughts of this Russian author to be still valuable. I think that his observations pointing to expensively paid social changes or his reflections on influences determining a historian's view on history are extraordinarily thought-provoking. Nevertheless, I cannot get rid of the conviction that a creative spirit of this Russian author is considerably disparaged by the way how revolutionarily he profiles himself within the intellectual discourse of the time, and how violently and, let me say, artificially he stipulates his postulates. In my reading of Tkachev, I have not found any single moment that would disprove my conviction that he himself serves as the confirmation of necessity of what he criticizes so much, which means, of subjective attitudes. For me, he represents a negative example of how essential is the 
form of presentation of the thoughts of a philosopher as well as the way of his engaging in social discourse concerning the certain thematic field. However, the fact is that his opinions were not marginal, but, on the contrary, they were resonating at the time. The study of Tkachev's works has next to strictly Narodnik context also a much broader significance: his thoughts represent a valuable basis for our understanding of history of thinking philosophical, political, and social one, within the Russian province in wider relations. These contexts present a historical continuum, and they have permanently marked a character not only of Russia but also of the whole world. I allude here to the mutual interactions of the Narodnik tradition and the legacy of Tkachev's works within the works of V. I. Lenin in particular.

As I already mentioned, this topic is extraordinarily delicate in the environment of the former Eastern Bloc. It is undoubtedly a topic which requires new readings that would be able to enrich still open questions, as one of the significant historians, Leszek Koiakowski, indicates: "The question of the independence of the Leninism ${ }^{1}$ as a distinctive variant of the Marxist doctrine and tactics is a long-term subject of disputes. Precisely speaking, these discussions dealt with the question if, in the relation to the Marxist tradition, the Leninism was a revisionist ideology or, contrarily, a perfect application of the main principles of the Marxism in a new political situation" [5, p. 392]. In this way, Koiakowski points to a problematic nature of Lenin's legacy. Let me note that this issue may be even more distinctive when the question concerns the connections of Lenin's works to the Russian Narodnism and Tkachev in particular. The extent of the issue as such is a peculiar question. However, I am convinced that new readings definitely require a substantial expert discussion on the nature of these new readings as well as on the nature of a systematic study of the topic - and I do not mean only "to dust off" the selected works of Lenin.

In this phase of my study, I do not have any ambition to outline the nature of new reading or to offer a clear and strict specification of the influence of Tkachev on Lenin. My intention is to give an idea of a possible nature of this relationship, to introduce some problematic features of the relationship and tasks which stand in front of everybody who would like to engage in such research.

As I mentioned above, I will proceed from the works of two Polish historians - Walicki [9] and Koiakowski [5]. The former emphasizes the year 1903 as the turning point - it was the year when the Russian Social Democratic Labour Party split into two factions: Bolsheviks and Mensheviks. According to Walicki [9], up to that year, the intensive and strictly ideological struggle between Marxists and Narodniks took place.

Proceeding from these sources, I will describe general frameworks which may be perceived as the conditions and circumstances of Lenin's possible confrontations with the Narodnik legacy. Subsequently, in the con-

${ }^{1}$ In relation to the term Leninism, it should be emphasized that neither in the work of A. Walicki [9] nor in the work of L. Koiakowski [5] can be found any difference in usage of the term Leninism and legacy, works, or opinions of V. I. Lenin himself. 
cluding part of this paper, I will sketch several forms of the interaction between the Narodnik tradition as such and the Leninism, and also between Tkachev and Lenin.

The environment in which young Lenin grew up and was intellectually shaped, distinctively under the influence of his elder brother Alexander, is fulfilled with thoughts of the radical Narodnism. It is possible to say that Lenin relates mostly to opinions produced by the radical and terroristic branch of the Narodnik movement, which, according to Walicki [9], linked Marxism (in the field of economics) with political radicalism of Tkachev. In this context, I would add that Narodnik ideas cannot be perceived only as an immediate and overall identification with economical-philosophical attitudes of the classical Marxism. In a considerable extent, there is emphasized an agrarian folk that cannot be fully identified with the proletariat of Marx ${ }^{1}$. In this atmosphere can be found also the origin of an attitude that is typical for a part of the radical Narodniks including Tkachev as well as for Lenin, the conviction that "underdeveloped countries are the closest to the socialism; civilizational development under capitalistic conditions does not increase but decrease the chances of the socialistic revolution. The only chance of socialism is an interruption of capitalistic development at the right moment. Socialism has a greater chance in Spain and Italy than in England, France, and Bismarckian Germany... Socialism has the greatest chances in Russia" [9, p. 239-240]. As we can see, a comparison of the positions of these subjects is possible. Walicki points to that also on another place of his work, when he defines three types of Russian revolutionary intelligence.

The first type is called the rational one, and it has a religious-emotional relationship to its doctrine. Walicki denotes the second type with the attribute "dogmatic-rational" because it uncritically accepts the cult of science. The third type of intelligence is the pragmatic one, which despises all the tenets and principles, it intends to achieve its goal at any cost, and "it is represented by Nechayev, Tkachev, and, in a considerable extent, by Lenin" [9, p. 249]. Walicki's approach enables not only to make a comparison of these subjects but also to identify their common attitudes.

${ }^{1}$ The main issue is that the agrarian way of life of the Russian servitude entailed a specific social order and social organization called obshchina. M. Broda refers to attitudes of the Russian Narodniks to the obshchina as follows: "An extraordinary attention of representatives of the intelligentsia was attracted by the Russian rural community obshchina and its belonging forms of social autonomous life, mir, in which they saw fundaments of future social and economic system in Russia" [3, p. 87]. I. Berlin in this connection notes: "All populists were agreed that the village commune was the ideal embryo of those socialist groups on which the future society was to be based" [2, p. 219]. R. Pipes writes: "Mir - the village commune - meant also 'the world'. The community restrained the unsocial impulses of the muzhik: the collective was superior to its individual members" [6, p. 158]. And L. Bazylow adds: "Without the permission of the whole mir, a peasant could not get rid of the rationed allotment or leave the village" [1, p. 325]. 
One of their similarities can be seen at the terminological level. Walicki [9] remarks that the term working class used by Lenin is definitely the Narodnik term and that it was the subject of mockery among the Marxist circles. In relation to the terminological field, he also points out to likeness between Lenin and Narodniks in his usage of the term democratic in his early works ${ }^{1}$ : "Word democratic is for Lenin (similarly as for the Narodniks) the opposite of word bourgeois, liberal" [9, p. 260].

However, the mentioned similarities are not inherent in the whole scale of questions concerning the relationship between Lenin and Narodniks. L. Koiakowski summarizes Lenin's ideological continuance and interest in the Narodnik tradition along with his intention to critically revaluate it as follows: "According to Lenin, the credit of Narodniks is that they were first who commented the ambiguity of capitalistic economy in Russia; but they were not able to answer the question they asked in another way than by a reactionary idea of the golden age" [5, p. 328]. We can see that Lenin is aside from the radical Narodnism closely linked just with Tkachev. Tkachev may be viewed as a linking element - a functional connection in the relationship between Lenin and radical Narodniks. In favour of this stance speaks also Walicki who in the connection with the teaching of the Narodnik Bakunin writes: “The most important link between Bakunin and Lenin is undoubtedly Tkachev. Bakunin imagined that after the triumph of the revolution, the centralized and authoritarian organization will quickly become unnecessary. Tkachev did not live in such a delusion. According to his opinion, after the victory of the revolution, a revolutionary dictatorship controlling overall social life (including spiritual life) will be inevitable. The power will belong to labourers supervised by the party (intelligence), even though they were a minority" [9, p. 267]. Here we can see an element that may be viewed as the shift to a crucial dimension of the paper, i.e. the possibility to perceive Tkachev as an immediate ideological predecessor of Lenin. Next to the ability to resist the "delusion" of the insignificance of the party after the victory of the revolution, the motive of minority emerges as well. That can be considered as the key motive on an axis of interaction between Tkachev and Lenin. I would like to emphasize that the abovementioned minority is nothing else than the revolutionary party. In this respect, Lenin does not hide his admiration for Tkachev, which probably follows from the fact that he could not find any substantial support for this matter in Marx's works. Koiakowski [5] points to the fact that although Marx did not equate the proletariat as a whole with the party, he "did not create any thoroughly elaborated theory of the party" [5, p. 400]. Marx was convinced about an unrestrained power of the proletariat, which Lenin resolutely denied. Lenin as well as Tkachev decisively refused to base a successful revolutionary campaign on unrestrained efforts of the labour movement, no matter how purposeful it would be. I agree with Koiakowski's opinion that "thus, according to Lenin, the key issue for a perspective revolution is theoretical

${ }^{1}$ A. Walicki mentions three significant periods of Lenin's works and activities: (1) up to the year 1903; (2) the revolutionary years 1905-1906; (3) after the year 1917 [9]. Thus, the mentioned early works fall under the first period. 
consciousness of the revolutionary movement, hence the consciousness which is not able to produce an unrestrained labour movement at any case" [5, p. 397]. The same attitude can be found also in Walicki: "An important role that Lenin assigned to a well-organized, hierarchically ordered, and the centrally controlled party had proceeded from a deep distrust of power and abilities of the unrestrained labour movement. Labourers dependent on themselves may at best arrive at a trade-unionism, in other words, at an ideological subjection to the bourgeoisie. The party (or rather, the leadership of the party) in Lenin's conception should have to play the same role as the intelligence in the Narodniks' conceptions, mainly in that of Nechayev and Tkachev" [9, p. 262]. If Walicki points to the key role of intelligence within the Narodnik conceptions of Nechayev and Tkachev, it should be reminded that Tkachev works with the motive of the party as well. To move forward from this statement, let me briefly refer to Lenin's immediate reaction to the mentioned organizational-theoretical dimension of Tkachev's legacy. That will also enable us to identify the most crucial feature of Lenin's relationship to the legacy of Tkachev.

I will proceed from A. Walicki' analysis of the well-known Lenin's work "What is to be done?"1 Walicki remarks that Lenin aimed to form a centralized and secret organization of professional revolutionists, and he notes that: "Lenin called the Tkachevian plan of gaining the power as grandiose" [9, p. 261].

More precise assessment may be found in Koiakowski: "Historians very often emphasize the role of Tkachev as a precursor of the Leninism. The conspiratorial Narodnik party Land and Liberty founded in 1876, owed Tkachev its organized character, but not its social opinions. Although Lenin spoke about the Narodnism, and mostly about its later form, with a great despise, he greatly appreciated the organizational tradition of the Narodnik conspiracy" [5, p. 336]. Besides the mentioned immediate statements of historians, the connection on the line Tkachev-Lenin is possible to notice also through a criticism addressed to Lenin: "Mensheviks - similarly as Rosa Luxemburg - constantly reproached Lenin's doctrine for "Blanquism”, for the effort to defeat the existing condition by a conspiracy, in other words, for following the conspiratorial ideology of Tkachev" [5, p. 407]. An organization of revolutionary activities, strict classification, discipline, and clearly defined frameworks; these were the motives of Tkachev' concept of the revolutionary party, which most notably attracted Lenin's attention. I would like to stress that I base that opinion on the secondary sources, i.e. on the texts of historians I worked with. I have chosen such an attitude intentionally, and I am aware of all admissible difficulties. It should be perceived as my expression of respect to the topic as well as to the reader. The second part of the paper aimed "only" to show that the link between Tkachev and Lenin does exist and that there are good reasons to examine the line Narod-

${ }^{1}$ The work with the identical title was written also by one of the devisers of the Narodnik movement N.G. Chernyshevsky in 1863, 39 years before Lenin. It is said that Lenin knew this Chernyshevsky's work by heart. 
niks-Tkachev-Lenin and vice versa. That context opens a great space for research, despite the hidden difficulties.

In the course of the interpretation of the ideological proximity of Narodnism to Leninism, we bumped into the issue of terminological ambiguity, of certain vagueness in Lenin's usage of terms. That is why Walicki sends a message to future historians, saying that "the essence of Leninism has to be uncovered in its hideaway" [9, p. 258]. He reflects the nature of the terminological issue as follows: "The basic complication as regards the writing about Leninism is the necessity "to read between the lines". Lenin did not subject his practice to "orthodoxness", however, he unwillingly renounced traditional "orthodox" formulations within the field of theory: instead of rejecting them, he preferred to use them and attributed them - often through strange interpretive methods - the completely different content. He tried to camouflage (also before himself) his revisionism at any cost" [9, p. 258]. All those who are interested in the study of Lenin's legacy should take that into account.

Walicki remarks that it is not possible to perceive Lenin's legacy as a chapter in the history of Marxism, and not at all as a part of the history of the international proletariat. "Leninism is something less and something more at the same time. The problem of Leninism is a problem of the whole Russia and all its history, along with its Europeness and Asianess, revolutionary movement, and four hundred years lasting Tsarist autocracy" [9, p. 269]. On the other place, Walicki emphasizes a need to conduct an interdisciplinary research and to take a wide scale of variables into consideration: "The investigation has to be done by constant selection of the importance of various Lenin's statements, by revealing diverse meanings in formulations which appear to be identic at the first glance, by permanent confrontation of Leninian thoughts with classical Marxism, with different kinds of the Russian Marxism, and with traditional Russian revolutionary thinking" [9, p. 258-259]. Walicki outlines many hidden issues and difficulties of such examination. In a certain sense, it may be viewed as a stimulus for historians, although the investigation can be never completed. As the credo of hermeneutics says, history has to be constantly overwritten...

In my view, the associated question, the problem arising in front of possible future investigations, is also the question with which I am going to conclude my paper: Can we say with a certainty, which ideas are the genuine ideas of Lenin? Should not we start with the selection between the authentic Lenin's legacy and the Leninism of "selected writings"?

\section{References}

1. Bazylow, L. (1985), Historia Rosji [Russian history], Ossolineum, Wrociaw.

2. Berlin, I. (1994), Russian Thinkers, Penguin Books, London.

3. Broda, M. (2003), Narodnickie ambiwalencje - między apoteozq ludu a terrorem [Narodniks' ambivalence. Between the apotheosis of the people and terror], Ibidem, Lodz.

4. Isakov, V.A. (2010), Petr Nikitich Tkachev, in: Tkachev, P.N., Izbrannoe [Selected works], ROSSPEN, Moscow, pp. 5-35. 
5. Koiakowski, L. (2009), Giywne nurty marksizmu [Main currents of Marxism], vol. 2, Wydawnictwo Naukowe PWN SA, Warszawa.

6. Pipes, R. (1997), Russia Under the Old Regime, Penguin Books, New York.

7. Pomper, P. (1993), The Russian Revolutionary Intelligentsia, Harlan Davidson, Wheeling.

8. Rydzewski, W. (1988), Filozofia polityczna rosyjskiego narodnictwa [Political philosophy of Russian Narodnizm], Uniwersytet Jagiellocski, Kraków.

9. Walicki, A. (2000), Idea wolności u myślicieli rosyjskich: studia z lat 1955-1959 [The idea of freedom among Russian thinkers: studies from 1955-1959], Wydawnictwo Uniwersytetu Jagiellocskiego, Krakow.

10. Walicki, A. (2005), Zarys myśli rosyjskiej: od oswiecenia do renesansu religijno-filozoficznego [Essay on of Russian thought from Enlightenment to the Religious and Philosophical Renaissance], Wydawnictwo Uniwersytetu Jagiellocskiego, Kraków.

11. Zverev, V.V. (2009), Russkoe narodnichestvo [Russian Narodnism], RAST Moscow.

12. Tkachev, P.N. (2010), Nauka v poezii i poeziya v nauke [Science in poetry and poetry in science], in: Tkachev, P.N., Izbrannoe [Selected works], ROSSPEN, Moscow, pp. 221-276.

13. Tkachev, P.N. (2010), Chto takoye partiya progressa [What the party of progress is], in: Tkachev, P.N., Izbrannoe [Selected works], ROSSPEN, Moscow, pp. 277-341.

14. Tkachev, P.N. (2010), Nabat (Programma zhurnala) [Nabat (Journal program)], in: Tkachev, P.N., Izbrannoe [Selected works], ROSSPEN, Moscow, pp. C. 453-466.

15. Tkachev, P.N. (2010), Nashi illyuzii [Our illusions], in: Tkachev, P.N., Izbrannoe [Selected works], ROSSPEN, Moscow, pp. 504-510.

16. Tkachev, P.N. (2010), Revolyutsiya i gosudarstvo [Revolution and state], in: Tkachev, P.N., Izbrannoe [Selected works], ROSSPEN, Moscow, pp. 515-526.

17. Tkachev, P.N. (2010), Narod i revolyutsiya [The people and the revolution], in: Tkachev, P.N., Izbrannoe [Selected works], ROSSPEN, Moscow, pp. 527-534.

18. Tkachev, P.N. (2010), Anarkhicheskoye gosudarstvo [Anarchist state], in: Tkachev, P.N., Izbrannoe [Selected works], ROSSPEN, Moscow, pp. C. 543-566.

19. Tkachev, P.N. (2010), Nakanune i na drugoy den' revolyutsii [On the eve and next day of the revolution], in: Tkachev, P.N., Izbrannoe [Selected works], ROSSPEN, Moscow, pp. C. 594-616.

20. Tkachev, P.N. (2010), Revolyutsiya i printsip natsional'nosti [Revolution and the principle of nationality], in: Tkachev, P.N., Izbrannoe [Selected works], ROSSPEN, Moscow, pp. 642-662.

21. Tkachev, P.N. (1990), Rol' mysli v istorii [The role of thought in history], in: Tkachev, P.N., Kladezi mudrosti rossiyskikh filosofov. Iz istorii otechestvennoy filosofskoy mysli [Fountains of wisdom of Russian philosophers. From the history of Russian philosophical thought], Pravda, Moscow, pp. 128-174.

22. Tkachev, P.N. (1990), Literaturnyye melochi [Literary trivia], in: Tkachev, P.N., Kladezi mudrosti rossiyskikh filosofov. Iz istorii otechestvennoy filosofskoy mysli [Fountains of wisdom of Russian philosophers. From the history of Russian philosophical thought], Pravda, Moscow, pp. 444-479.

23. Tkachev, P.N. (1975), Ocherki iz istorii ratsionalizma [Essays on the history of rationalism], in: Tkachev, P.N., Sochineniya v 2 tomakh [Works in 2 vols.], vol. 1, Mysl', Moscow, pp. 119-156. 
24. Tkachev, P.N. (1975), Utopicheskoye gosudarstvo burzhuazii [Utopian state of the bourgeoisie], in: Tkachev, P.N., Sochineniya $v 2$ tomakh [Works in 2 vols.], vol. 1, Mysl', Moscow, pp. 328-373.

25. Tkachev, P.N. (1975), Zakon obshchestvennogo samosokhraneniya [Public selfpreservation law], in: Tkachev, P.N., Sochineniya $v 2$ tomakh [Works in 2 vols.], vol. 1, Mysl', Moscow, pp. 406-460. 